\title{
Males of Ichthyofilaria argentinensis Incorvaia, 1999 and I. bergensis (Wülker, 1930) (Dracunculoidea: Guyanemidae): new morphological aspects and emendation of the generic diagnosis
}

\author{
Delfina M.P. Cantatore ${ }^{1,2}$, Paolo Merella ${ }^{3}$ and Juan T. Timi ${ }^{1,2}$ \\ ${ }^{1}$ Laboratorio de Parasitología, Departamento de Biología, Facultad de Ciencias Exactas y Naturales, Universidad Nacional de Mar \\ del Plata, Funes 3350, Mar del Plata (7600), Argentina; \\ ${ }^{2}$ Concejo Nacional de Investigaciones Científicas y Técnicas (CONICET), Argentina; \\ ${ }^{3}$ Sezione di Parassitologia e Malattie Parassitarie, Dipartimento di Biologia Animale, Università di Sassari, Via Vienna 2, Sassari \\ (07100), Italy
}

\begin{abstract}
The adult male of dracunculoid nematode Ichthyofilaria argentinensis Incorvaia, 1999 (Guyanemidae) is described for the first time based on specimens found in the swimbladder of its type host, Merluccius hubbsi Marini (Merlucciidae), caught off the coast of Buenos Aires, Argentina (western Atlantic Ocean). In addition, the males of Ichthyofilaria bergensis (Wülker, 1930) Køie, 1993 are redescribed from specimens collected from the body cavity and visceral surface of Molva macrophthalma (Rafinesque) (Lotidae) caught in the western Mediterranean Sea, off the coast of Sardinia. Light and scanning electron microscopy examinations revealed some new morphological features for the genus, such as a pair of deirids located near the end of muscular oesophagus, the body wall conspicuously twisted immediately anterior to the cloaca, the presence of a copulatory plate, one pair of adcloacal papillae and a pair of phasmids situated on the posterior half of the tail. On the basis of this material, the generic diagnosis of Ichthyofilaria is modified to include some of these newly observed features, as well as to indicate the absence of spicules. The diagnosis of Guyanemidae is extended to include that a copulatory plate and/or two spicules may be present as characteristics for this family.
\end{abstract}

Keywords: male nematodes, Ichthyofilaria, Guyanemidae, generic emendation

Dracunculoid nematodes of the genus Ichthyofilaria Yamaguti, 1935 are parasites of tissues, swimbladder and abdominal cavity of marine fishes (Moravec 2006). To date, this genus comprises six nominal species: I. dasycotti Yamaguti, 1935, a parasite of Dasycottus setiger Bean (Cottidae), and I. japonica Moravec et Nagasawa, 1985, found in Sebastes schlegelii Hilgendorf (Sebastidae), both from Japanese waters; I. canadensis Appy, Anderson et Khan, 1985, a parasite of Lycodes lavalaei Vladykov et Tremblay and L. vahlii Reinhardt (Zoarcidae) from the Atlantic Canadian waters; I. bergensis (Wülker, 1930) Køie, 1993, a parasite of Molva dypterygia (Pennant) (Lotidae) from the northeastern Atlantic; I. argentinensis Incorvaia, 1999, found in the swimbladder of Merluccius hubbsi Marini (Merlucciidae) from the Argentine Sea and I. novaecaledoniensis Moravec et Justine, 2009, recently described from Hoplichthys citrinus Gilbert (Hoplichthyidae) from New Caledonian waters (Moravec 2006, Moravec and Justine 2009). Undescribed specimens of this genus were also found in Gaidropsarus granti (Regan) (Lotidae) by Pais et al. (2008); according to the au- thors, parasites are very similar to I. bergensis, but due to differences in a number of unmentioned morphometric characters they are not attributed to this species.

Males of this genus have been reported only twice, by Køie (1993) and Pais et al. (2008), but only the former provided a brief description of them; the rest of the species are known solely from the large-sized females.

In the present study, males of I. argentinensis are described and illustrated for the first time. Furthermore, additional samples of male specimens of $I$. bergensis are studied and redescribed. Some morphological features observed in the described material justify a modification of the generic diagnosis of Ichthyofilaria and provide new data for extending the diagnosis of the family Guyanemidae Petter, 1974.

\section{MATERIALS AND METHODS}

A total of 41 specimens of Merluccius hubbsi caught by commercial fleet off the coast of Buenos Aires Province, Argentina (western Atlantic Ocean), in August 2009, were examined for males of Ichthyofilaria argentinensis. Nematodes were col-

Address for correspondence: D.M.P. Cantatore, Laboratorio de Parasitología, Departamento de Biología, Facultad de Ciencias Exactas y Naturales, Universidad Nacional de Mar del Plata, Funes 3350, Mar del Plata (7600), Argentina. Phone: +54 223 4752426; Fax: +54 223 4753150; E-mail: cantator@mdp.edu.ar 
lected from the swimbladders, fixed in $4 \%$ formaldehyde solution and then transferred to $70 \%$ ethanol for storage until being studied and measured. An additional sample of male nematodes of $I$. bergensis fixed in 70\% ethanol was also available for morphological studies. These specimens were collected from Molva macrophthalma (Rafinesque) caught during the MEDITS-2007 trawl survey in the coastal waters of Sardinia (western Mediterranean Sea) in August 2007. Morphology of some females included in this sample allowed the confirmation of their belonging to $I$. bergensis.

Line drawings were made with the aid of a drawing tube. Some specimens were used for scanning electron microscopy (SEM); they were fixed in $3 \%$ glutaraldehyde in $0.1 \mathrm{M}$ sodium cacodylate buffer ( $\mathrm{pH}$ 7.2-7.4) and then stored in the same buffer. Nematodes were dehydrated using a series of ethanol washes, dried by evaporation with hexamethyldisilazane, coated with gold palladium, and scanned in a JEOL JSM 6460-LV scanning electron microscope (JEOL, Tokyo, Japan).

All measurements are given in micrometres $(\mu \mathrm{m})$, unless otherwise indicated, as mean \pm standard deviation with ranges in parentheses, followed by the number of specimens measured (n). Prevalence of infection was calculated according to Bush et al. (1997).

The material studied was deposited in the Helminthological Collection of the Museo de La Plata, La Plata, Argentina, and in the Helminthological Collection of the Institute of Parasitology, Biology Centre, Academy of Sciences of the Czech Republic, České Budějovice, Czech Republic.

The taxonomy and scientific names of fishes are in accordance with FishBase (Froese and Pauly 2010).

\section{RESULTS}

\section{Ichthyofilaria argentinensis Incorvaia, 1999}

Figs. 1, 2

Description of male: Body whitish, filiform, almost cylindrical, $6.27 \pm 0.66(5.15-7.27) \mathrm{mm}$ long $(\mathrm{n}=15)$, maximum width $79 \pm 9$ (68-100) near middle of body $(\mathrm{n}=15)$. Cuticle with fine transverse striations. Cephalic end rounded. Oral aperture small, oval, surrounded by a pair of large lateral amphids and four submedian pairs of cephalic papillae, inner circle of cephalic papillae not observed. Deirids located at $315 \pm 22$ (281-358) from anterior end $(n=13)$, sometimes asymmetrically located near end of muscular oesophagus. Muscular oesophagus $287 \pm 44(237-375)$ long $(n=13)$, glandular oesophagus short, provided with long posterior appendage, directed backwards, ending in ligament attached to body wall, $1.21 \pm 0.12(1.1-1.5) \mathrm{mm}$ long $(\mathrm{n}=13)$, with four slight constrictions not evident in all specimens. Intestine not observed, probably atrophied. Nerve ring encircling muscular oesophagus at $204 \pm 18 \quad(175-238)(n=14)$ from anterior extremity. Excretory pore located $221 \pm 37$ $(129-265)(n=13)$ from anterior end. Testis single, occupying nearly whole nematode body. Tail conical, ventrally curved $149 \pm 8(138-163)$ long $(n=15)$, with sharply pointed terminal spike $2 \pm 0.6(1.7-2.8) \mu \mathrm{m}(\mathrm{n}=3)$ long. Body wall conspicuously twisted immediately anterior to cloaca. Copulatory organs represented by small, unpaired sclerotized copulatory plate, $17 \pm 2(15-19)$ long $(n=13)$. Three pairs of caudal papillae present: one pair adcloacal; other two posterior to cloaca, sometimes with asymmetrical arrangement. First postcloacal papilla (left) situated at $46 \pm 9(25-65)(\mathrm{n}=15)$ and second postcloacal papilla (left) at $75 \pm 7(60-90)(n=15)$ from cloaca. One pair of phasmids located $110 \pm 14(80-130)(n=8)$ from cloacal opening.

H o s t: Argentine hake, Merluccius hubbsi Marini (Gadiformes: Merlucciidae).

L o c a lity: Off the coast of Buenos Aires Province, Argentina (western Atlantic) (collected in August 2009).

Site of infection: Serose layers of swimbladder.

Prevale n c e: Males in 15 out of 41 hakes (37\%) (prevalence of infection by female parasites $92.7 \%$ ).

Specimens deposited: 8 voucher specimens Coll. No. MLP-6145 in the Helminthological Collection of the Museo de La Plata, La Plata, Argentina, 8 voucher specimens Coll. No. N-950 in the Helminthological Collection of the Institute of Parasitology, Biology Centre of the Academy of Science of the Czech Republic, České Budějovice.

Ichthyofilaria bergensis (Wülker, 1930) Køie, 1993

Fig. 3

Redescription of male: Body whitish, filiform, almost cylindrical, $5.5 \pm 0.6(4.4-6.3) \mathrm{mm}$ long $(\mathrm{n}=14)$, maximum width $23 \pm 3$ (18-30) near middle of body $(\mathrm{n}=15)$. Cephalic end rounded. Cephalic papillae not observed. Deirids located at $249 \pm 30$ (204-304) from anterior end $(n=15)$, sometimes asymmetrically located near end of muscular oesophagus. Muscular oesophagus $259 \pm 35$ (212-314) long $(\mathrm{n}=10)$, glandular oesophagus short, provided with long posterior appendage, directed backwards, $1.2 \pm 0.2(1.1-1.4) \mathrm{mm}$ long $(\mathrm{n}=2)$. Intestine not observed, probably atrophied. Nerve ring encircling muscular oesophagus at $166 \pm 24(128-218)(n=12)$ from anterior extremity. Excretory pore located $203 \pm 22$ $(170-228)(n=7)$ from anterior end. Testis single, occupying nearly whole nematode body. Tail slender, $206 \pm 27$ (143-239) long $(n=14)$, with sharply pointed terminal spike $1 \pm 0.1(1.0-1.3) \mu \mathrm{m}(\mathrm{n}=3)$. Body wall conspicuously twisted immediately anterior to cloaca. Copulatory organs represented by small, unpaired sclerotized copulatory plate, $5 \pm 1(4-7)$ long $(n=14)$. Three pairs of caudal papillae present: one pair adcloacal; the other two posterior to cloaca, sometimes with asymmetrical arrangement. First postcloacal papilla (left) situated at $26 \pm 3$ (21-29) $(\mathrm{n}=14)$ and second postcloacal papilla (left) at $53 \pm 4$ $(43-60)(n=14)$ from cloaca. One pair of phasmids located $111 \pm 7(99-120)(n=7)$ from cloacal opening.

Host: Spanish ling, Molva macrophthalma (Rafinesque) (Gadiformes: Lotidae).

L o c a lity: Coastal waters of Sardinia Island, western Mediterranean Sea (collected in August 2007). 

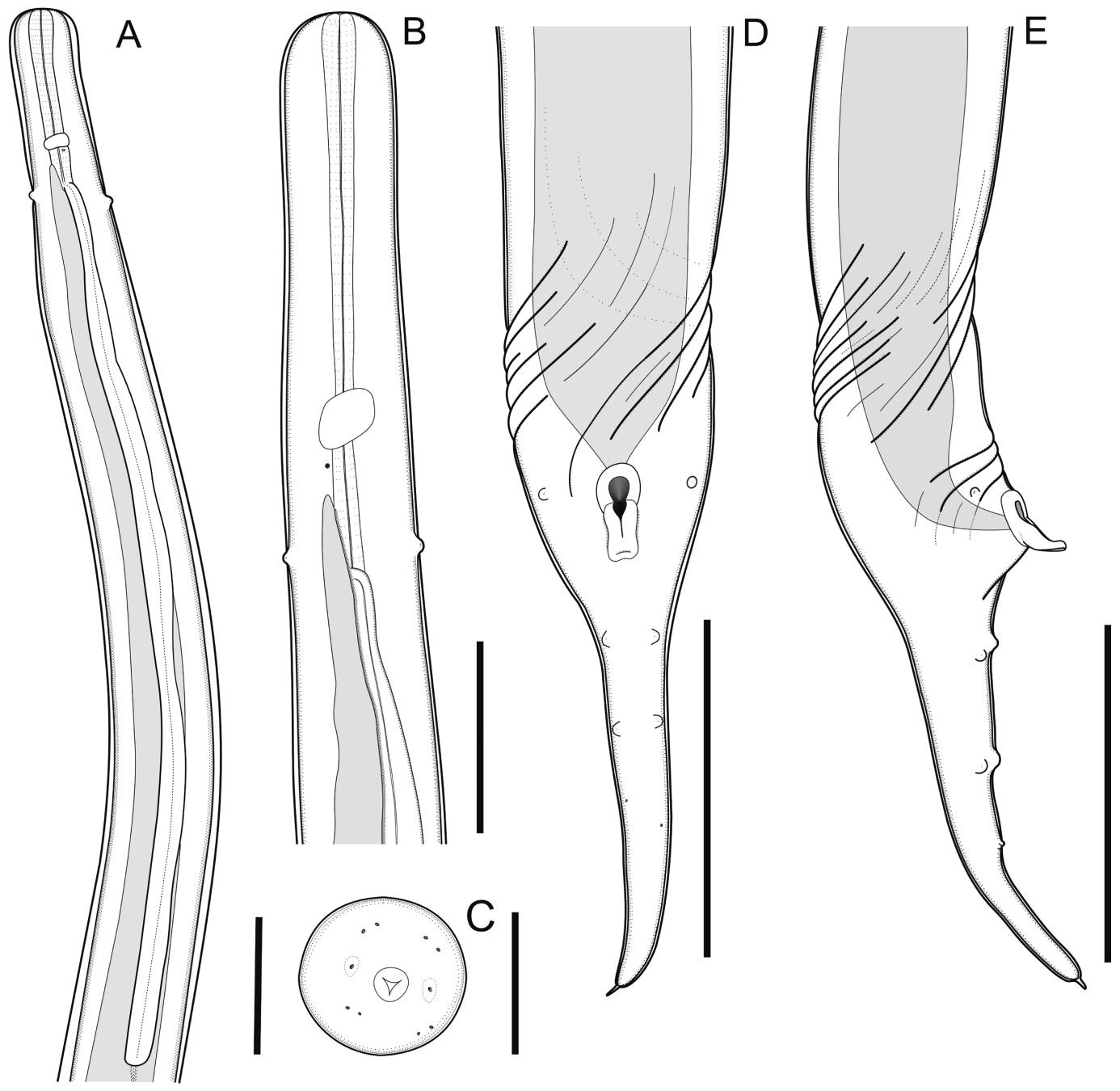

Fig. 1. Ichthyofilaria argentinensis Incorvaia, 1999, adult male. A - anterior part of body, ventral view; B - detail of anterior end, ventral view; $\mathbf{C}$ - cephalic end, apical view; $\mathbf{D}$ - posterior end, ventral view; $\mathbf{E}$ - posterior end, lateral view. Scales bars: $\mathrm{A}=1000 \mu \mathrm{m} ; \mathrm{B}, \mathrm{D}, \mathrm{E}=100 \mu \mathrm{m} ; \mathrm{C}=50 \mu \mathrm{m}$.

Site of infection: Body cavity and surface of visceral organs.

Prevale n c e: Males in 6 out of 13 fish (46\%) (prevalence of infection by female parasites $62 \%$ ).

Specimens deposited: 5 voucher specimens Coll. No. N-951 in the Helminthological Collection of the Institute of Parasitology, Biology Centre of the Academy of Science of the Czech Republic, České Budějovice.

Diagnosis of Ichthyofilaria Yamaguti, 1935 (modified from Moravec 2006)

Body cylindrical, with narrowed anterior and posterior ends; cephalic end rounded, sometimes with four submedian lobe-like projections, posterior end pointed. Cuticle smooth or finely striated. Mouth simple; cephalic papillae present. Oesophagus short, divided into anterior muscular and posterior glandular portions; latter with posteriorly oriented appendix. Intestine posteriorly ending in ligament attached to body wall. Anterior ovary rudimentary, posterior ovary cylindrical, extending to near tail. Uterus continuous, filled with larvae. Male with attenuated tail and small, unpaired sclerotized copulatory plate. Body wall conspicuously twisted immediately anterior to cloaca. Three pairs of caudal papillae present; one pair adcloacal, other two postcloacal; precloacal papillae absent. Parasites of tissues, swimbladder and abdominal cavity of marine fishes. Type species: I. dasycotti Yamaguti, 1935.

\section{DISCUSSION}

Nematodes of the spirurid superfamily Dracunculoidea Cameron, 1934 represent a large and diverse group of parasites with a worldwide distribution, which infect various tissues and organ cavities of vertebrates, mainly fishes (Moravec 2004). The most recent revision of their classificatory system has been proposed by Moravec (2006), where the family Guyanemidae Petter, 1974 was redi- 

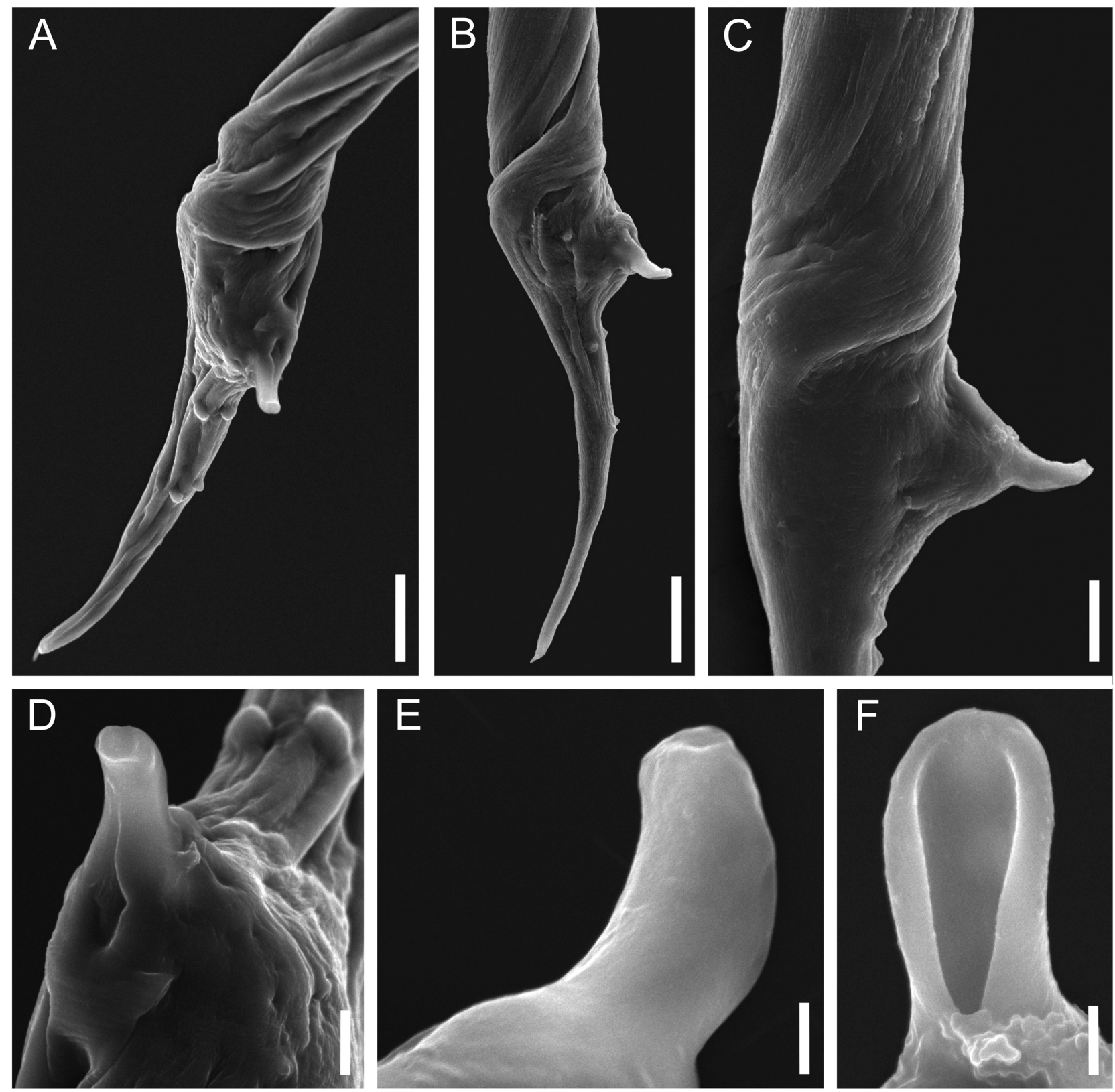

Fig. 2. Ichthyofilaria argentinensis Incorvaia, 1999, scanning electron micrographs of adult male. A - posterior end, ventral view; $\mathbf{B}$ - posterior end, lateral view; $\mathbf{C}$ - copulatory plate region, lateral view; $\mathbf{D}-\mathbf{F}$ - copulatory plate, anterior, lateral and posterior views. Scales bars: $\mathrm{A}, \mathrm{B}=20 \mu \mathrm{m} ; \mathrm{C}, \mathrm{D}=5 \mu \mathrm{m} ; \mathrm{E}, \mathrm{F}=2 \mu \mathrm{m}$.

agnosed and subdivided into the new subfamilies Guyaneminae Petter, 1974 and Travassosneminae Moravec, 2006. Furthermore, the genus Ichthyofilaria Yamaguti, 1935 was emended and transferred from Philometridae Baylis et Daubney, 1926 to Guyanemidae, subfamily Travassosneminae.

Females of $I$. argentinensis were originally described by Incorvaia (1999) and later redescribed by Timi et al. (2001). Further studies on parasites of Argentine hake only recorded females of $I$. argentinensis (see Sardella and Timi 2004); in consequence, this is the first description of the male for this species.
The female of $I$. bergensis was originally described as Philometra bergensis by Wülker (1930) and later transferred to the genus Ichthyofilaria by Køie (1993). To date, the unique available description of males of Ichthyofilar$i a$ is that made by Køie (1993) for I. bergensis found in the body cavity and surface of visceral organs of Molva dypterygia (Pennant) from the northeastern Atlantic. This description is not detailed as it was based only on three specimens, being illustrated only by two photographs at low magnification. Therefore, the presence of I. bergensis in Molva macrophthalma (Rafinesque) from Sardinian 

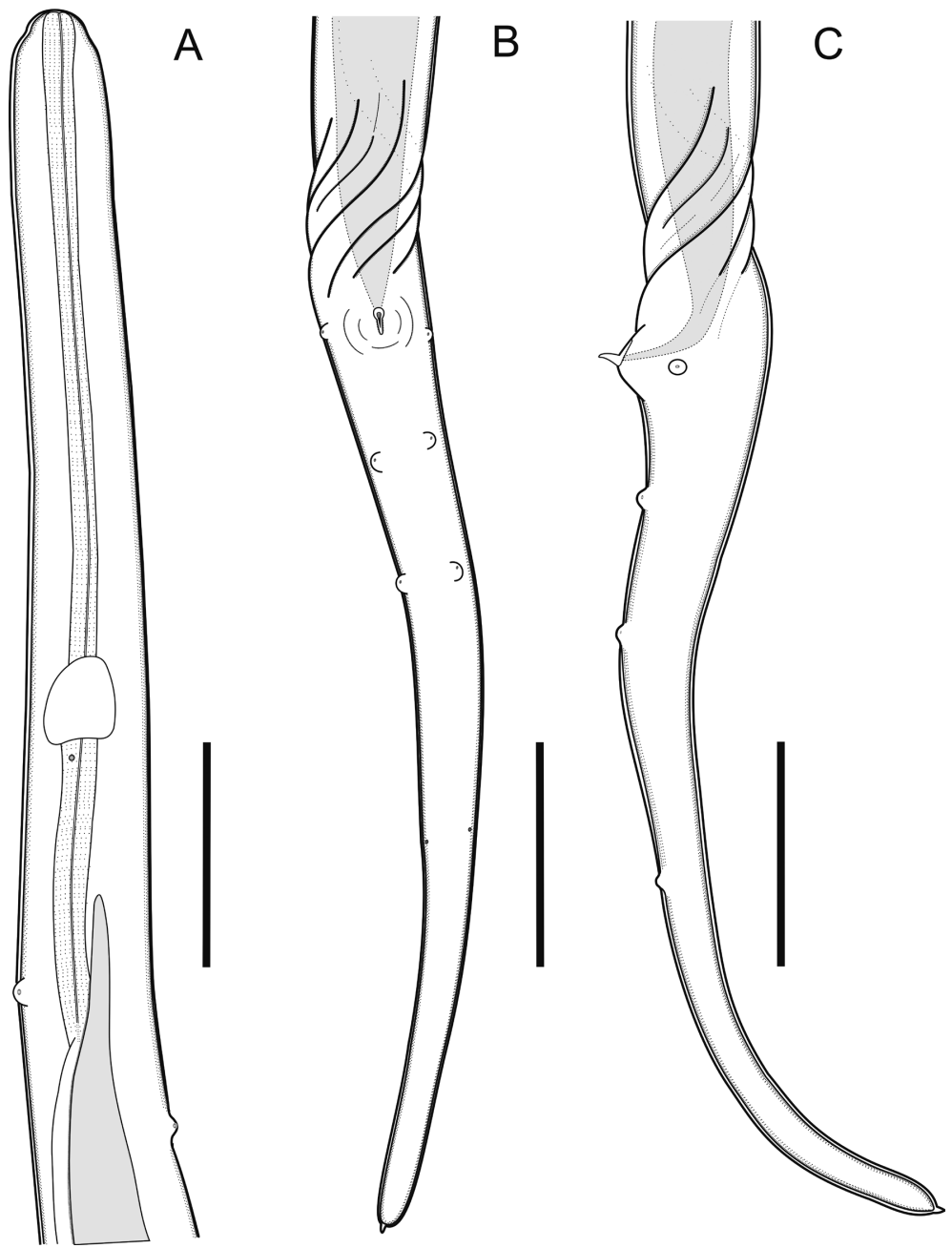

Fig. 3. Ichthyofilaria bergensis (Wülker, 1930) Køie, 1993, adult male. A - anterior end, ventral view; B - posterior end, ventral view; $\mathbf{C}$ - posterior end, lateral view. Scales bars $=50 \mu \mathrm{m}$.

waters (western Mediterranean Sea) represents a new host and locality record for this species.

Based on the material examined in the present study, adult males of both species of Ichthyofilaria are characterized by the presence of a small, unpaired sclerotized copulatory plate, three pairs of caudal papillae (one adcloacal and two postcloacal) and the body wall conspicuously twisted immediately anterior to the cloaca. Position of deirids and phasmids are also described for the first time for males of Ichthyofilaria. Nevertheless, males of these two species can mutually be distinguished by the shape and size of the tail and the relative size of the copulatory plate with respect to the tail length. Moreover, they also differ in the general measurements, the males of $I$. argentinensis being longer and wider.

Thus, the morphology of described specimens provides new information of significant taxonomic value that is not according to the current generic diagnosis. In consequence, it was necessary to modify the diagnosis of this genus in regard to various taxonomically important morphological features. The presence of an atrophied intestine is congruent with the characteristic of this organ in females, which is non-functional in most species of Ichthyofilaria (see in Yamaguti 1935, Appy et al. 1985, Timi et al. 2001, Moravec 2006, Moravec and Justine 2009). However, since females of $I$. bergensis have apparently a functional anus (Køie 1993), this feature was not included in the generic diagnosis.

Firstly, the presence of fine transverse striations on the cuticle could only be observed under scanning electron microscopy (SEM). Unfortunately, none of the previously described species of Ichthyofilaria have been studied with the use of SEM, so this particular aspect needs further detailed studies. Secondly, the presence of a sclerotized copulatory plate, erroneously interpreted as "two small, triangular spicules protruded from the genital opening" by Køie (1993). Moreover, the diagnosis of Guyanemidae needs to be extended, as well, to indicate that two spicules and/or a sclerotized copulatory plate may be present or absent. This feature is also supported by the recent descrip- 
tion of the guyanemid Moravecia argentinensis Braicovich, Moravec et Timi, 2007, a species with males having a small, V-shaped sclerotized structure (copulatory plate), in addition to markedly short spicules (Braicovich et al. 2007). Other important features are the pair of adcloacal papillae and the pair of phasmids situated on the posterior half of the tail, which were overlooked in I. bergensis by Køie (1993). The number and distribution of caudal papillae has, in many dracunculoids, a higher value than only a specific character (Moravec 2006); therefore, the presence of three pairs of caudal papillae (one adcloacal and two postcloacal) could represent a generic character. In addition, the conspicuous twisted body wall immediately anterior to cloaca has not been previously reported for any other dracunculoid nematode.

According to Moravec (2004), the present classification system of dracunculoids is unsatisfactory, and a tax- onomic revision based on detailed studies of individual species is a prerequisite for developing a new one. Particularly, a detailed morphological description of males surely will improve the possibility of a correct assignment of the species to their respective genus and family. The contribution of male features to the homogeneity of the genus Ichthyofilaria, as well as to the extension of the family diagnosis, is a clear example of the relevance of male morphology for the systematics of Dracunculoidea.

Acknowledgements. We thank Dr. Maria Cristina Follesa for providing M. macrophthalma samples (MEDITS trawl survey 2007), Dr. Ana L. Lanfranchi for her assistance in sampling, and Lic. Juan P. Lancia for his help in making the drawings. This study was partly supported by grant EXA 442/08 from Universidad Nacional de Mar del Plata; PICT 02199/07 from FONCYT and PIP 112-200801-00024 from CONICET. This work is part of the doctoral thesis of D.M.P.C.

\section{REFERENCES}

Appy R.G., Anderson R.C., Khan R.A. 1985: Ichthyofilaria canadensis n. sp. (Nematoda: Dracunculoidea) from eelpouts (Lycodes spp.). Can. J. Zool. 63: 1590-1592.

Braicovich P., Moravec F., Timi J.T. 2007: New species of Moravecia (Nematoda: Dracunculoidea) from the body cavity of marine perciform fish Percophis brasiliensis in Argentina. J. Parasitol. 93: 353-356.

Bush A.O., Lafferty K.D., Lotz J.M., Shostak A.W. 1997: Parasitology meets ecology on its own terms: Margolis et al. revisited. J. Parasitol. 83: 575-583.

Froese R., Pauly D. (Eds.) 2010: FishBase. World Wide Web electronic publication, www.fishbase.org, 3/2010.

INCORVAIA I.S. 1999: Ichthyofilaria argentinensis sp. nov. (Nematoda: Philometridae) parásita de Merluccius hubbsi (Pisces: Merlucciidae). Cienc. Mar. 25: 439-444.

KøIЕ M. 1993: Nematode parasites in teleosts from 0 to $1540 \mathrm{~m}$ depth off the Faroe Islands (The North Atlantic). Ophelia 38: 217-243.

Moravec F. 2004: Some aspects of the taxonomy and biology of dracunculoid nematodes parasitic in fishes: a review. Folia Parasitol. 51: 1-13.

Moravec F. 2006: Dracunculoid and Anguillicoloid Nematodes Parasitic in Vertebrates. Academia, Prague, 634 pp.

Moravec F., Justine J.-L. 2009: New data on dracunculoid nematodes from fishes off New Caledonia, including four new species of Philometra (Philometridae) and Ichthyofilaria (Guyanemidae). Folia Parasitol. 56: 129-142.

Pais A., Merella P., Follesa M.C., Garippa G., Golani D. 2008: New data on Gaidropsarus granti (Regan, 1903) (Gadiformes: Lotidae) from the Mediterranean Sea, with emphasis on its parasites. Sci. Mar. 72: 461-468.

Sardella N.H., Timi J.T. 2004: Parasites of Argentine hake in the Argentine Sea: population and infracommunity structure as evidence for host stock discrimination. J. Fish Biol. 65: $1472-1488$.

Timi J.T., Navone G.T., Sardella N.H. 2001: Redescription of Ichthyofilaria argentinensis Incorvaia, 1999 (Nematoda: Philometridae) parasite of Merluccius hubbsi (Pisces: Merlucciidae) from Argentina. Folia Parasitol. 48: 139-142.

Wülker G. 1930: Über Nematoden aus Nordseetieren II. Zool. Anz. 88: 1-16.

Yamaguti S. 1935: Studies on the helminth fauna of Japan. Part 9. Nematodes of fishes, 1. Jpn. J. Zool. 6: 337-386.

Accepted 25 May 2010 